\title{
POTENTIAL COMPETITION, ACTUAL COMPETITION, AND ECONOMIC WELFARE
}

\author{
P. DASGUPTA and J.E. STIGLITZ \\ Princeton University, Princeton, NJ 08544, USA
}

\section{Introduction ${ }^{1}$}

Though the origins of anti-trust legislation, at least in the United States, undoubtedly lie in late nineteenth century Populist sentiments, its current intellectual foundations rest on modern welfare economics. These intellectual foundations provide more than just rhetoric, as courts have increasingly relied on the testimony of economists to interpret and reinterpret the inevitably vague language of the legislation.

The reliance on modern welfare economics is somewhat paradoxical. For the assumptions underlying the Fundamental Theorem of Welfare Economics are peculiarly ill-suited to deal with competition in the central area to which anti-trust is applied - the industrial sectors of modern economies. These sectors are characterized by important non-convexities, which admittedly present inherent problems for competition. The competition that does take place is as likely to take the form of product and $R \& D$ competition, rather than price competition. Product competition plays no role in the conventional welfare paradigm, which assumes a complete set of commodities. ${ }^{2}$ And it is not that Arrow and Debreu simply forgot to include technical change in their formulations: the natural assumptions underlying the analysis of the production. marketing, and utilization of knowledge are basically inconsistent with those underlying the Arrow Debreu model. ${ }^{3}$

\footnotetext{
'Invited paper, European Economic Association meetings, Copenhagen, August, 1987. Financial support from the National Science Foundation and the Hoover Institution is gratefully acknowledged.

${ }^{2}$ The presence of non-convexities in production is central in explaining why only a finite subset of the set of possibie commodities is in fact produced.

${ }^{3}$ Technical change is characterized by non-convexities in its production [Radner and Stiglitz (1984)]. If technology exhubits, say, constant returns to scale at a fixed technology, when inputs devoted to $\mathrm{R} \& \mathrm{D}$ are included. it exhibits non-convexities. The value of information may increase with the scale of production. While conventional theory focuses on markets for homogeneous commoditues, each piece of new knowledge must be different from previously produced knowledge. Knowledge has many of the properties of public goods, it being both difficult and undesirable to exclude. Markets for knowledge are, at best, imperfect, and, as we have argued
} 


\section{Contestability: The promise of a more general theory}

It is thus not surprising that so many economists, and anti-trust lawyers, found so attractive the suggestion, originally put forth by such Chicago economists as Demsetz and formalized by Grossman (1981) and Baumol, Panzar and Willig (1982), that even in the presence of large non-convexities, markets may be efficient. Potential competition, not actual competition, was all that was required to ensure both efficiency and that the gains from efficiency would be passed along to consumers.

There was even a suggestion that potential competition would resolve the problems posed by technological change. Adam Smith's vision of the virtues of capitalism had as much to do with his belief in the drive for innovation which it provided as it did with the kinds of considerations which have been the focus of modern welfare economics. Schumpeter forcefully criticized the textbook economics of his day not only because they were misguided in their focus, but because their conception of modern capitalism was simply wrong. $\mathrm{He}$ argued that there would be temporary monopolies in each market. Competition would force such high expenditures on R\&D that profits would be driven down to zero. To Schumpeter, this dynamic efficiency was far more important than the static efficiency that seemed to be the concern of other economists.

If the arguments that even in the presence of non-convexities which lead to only one firm producing in a market potential competition ensures efficient outcomes were correct, and if those arguments could be extended to the particular kinds of non-convexities associated with technological change, ${ }^{4}$ then we would at last have an intellectual foundation for the belief in the efficiency of capitalist industrial economies; anti-trust policy would, however, have a much more circumscribed role than depicted in the traditional analysis. A large market share would, for instance, not be indicative of the desirability of government intervention.

\section{Disappointment: The pervasiveness of inefficiencies with actual and potential competition}

The hope that a theory of potential competition would at last enable the extension of welfare economics to modern industrial economies, while it may have been well funded, was not well founded.

For even by the mid-70s, it was clear that free entry - the zero profit

elsewhere (Dasgupta and Stiglitz (1980a, 1908b)), product markets in which the production of new knowledge (R\&D) is important are almost inevitably imperfectly competitive. For a more general discussion of these issues, see Stiglitz (1987).

${ }^{4}$ Technological change presented further problems to the traditional paradigm than just those associated with non-convexities, as we suggested in the previous footnote. 
condition - was not sufficient to ensure economic efficiency in the presence of non-convexities. Dixit and Stiglitz had shown that only under certain stringent conditions would a market achieve a constrained Pareto efficient outcome (where the government was precluded from providing lump sum subsidies to cover the fixed costs associated with the non-convexities). ${ }^{s}$

Indeed, while potential competition might alter behavior - firms mizht undertake greater capacity expansion, invest in more durable machines, engage in a host of other entry deterrence devices - welfare might not be increased relative to what it would have been in the absence of competition; a fortiori, there was no presumption that potential competition ensured any kind of (constrained or unconstrained) optimum. Stiglitz (1981) showed, for instance, that the threat of entry lead to responses by the incumbent firms which enable them to deter entry; thus potential entrants are no better off; but incumbent profits are lower. Some of the entry deterring actions could, at the same time, hurt consumers. For instance, a monopolist owner of a natural resource would raise prices (conserve on its stock of oil) to deter entry.

If potential competition may, under some circumstances, be Pareto inefficient, a fortiori, there will be circumstances in which, under some less stringent welfare criterion, welfare would be lowered, in which though some gain and others lose, the gains are, in some sense, smaller than the losses.

\section{Potential and actual competition}

Just as there is no clear relationship between potential competition and economic welfare, the relation between potential competition and actual competition is also complex. It has proven useful to divide the analysis of market equilibrium into two stages, before the entrant enters the market, and after. Baumol, Panzar, and Willig recognized that for potential competition to ensure zero profits sunk costs could not be too large. It turns out, however, that if there are even small sunk costs, potential competition may not be effective in ensuring either that profits go to zero or that efficient outcomes obtain.

There are two senses in which sunk costs may be small. They may be small relative to variable costs of production; or they may be relatively unsunk; that is, we customarily think of unrecoverable commitments of resources which are 'used' up in a day or a week as hardly being sunk: they are more in the nature of variable costs than sunk investment costs.

It is easy to show that even if sunk costs are small in the first sense,

\footnotetext{
${ }^{5}$ The response that, under the stipulated conditions, a single multiproduct firm ought to, and presumably would, take over the entire industry, charging Ramsey prices, while at first seeming persuasive, was quickly found to be inadequate. See Sappington and Stiglitz.
} 
potential competition may be completely ineffective. Assume that there are a large number of identical firms, except that one has already entered the market. Each faces a constant returns to scale technology, once it invests $\varepsilon$ in sunk costs. They all believe that if there is more than one firm in the market, there will be Bertrand competition, so that price will fall to the marginal cost of production, $c$. In this case, the incumbent firm can charge the monopoly price; his behavior is completely unaffected by the presence of potential competitors. They will not enter, because they know that, were they to enter, they would fail to recover their $\varepsilon$ sunk costs.

It is also possible to show that if sunk costs are small in the second sense (that is, they are not very sunk) then while potential competition may drive profits to zero, price remains at the monopoly level; potential competition is welfare decreasing, as all profits are dissipated in excessive capacity expenditures. Consider an industry in which all costs are sunk; an expenditure of $F$ allows the firm to produce an unlimited quantity at a zero marginal cost for a period of $T$ years. This industry is a natural monopolist. A monopolist would clearly charge the revenue maximizing price, replacing the machine every $T$ periods. The threat of entry forces him to alter his behavior. He knows that were he to wait until his old machine wears out, it would pay some rival to enter at some prior date; though in the period during which both firms were in the market, if there were Bertrand competition, profits (indeed, price) would be zero, after his machine wears out, the original incumbent would not want to replace the machine. The entrant would then be in a position to make monopoly profits. There is a date, say $\hat{T}$, prior to scrapping the old machine, such that if the incumbent constructs a new machine, it would not pay any rival to enter. Potential competition has simply resulted in excess capacity over the period $\{T-\hat{T}\}$; price remains at the monopoly level. Further, as $T$, the lifetime of the machine, becomes shorter (hence costs become less sunk), price remains at the monopoly price, while profits shrink to zero.

These results are chosen to be dramatic, to show that potential competition does not suffice. We have explored a variety of other models. A general principle emerges: the more competitive ex post competition (competition is after entry) the less effective is the market discipline provided by potential competition. If we had assumed, for instance, that the commodities produced by the different firms were imperfect substitutes, then potential competition would serve as a discipline device, provided sunk costs were not too large; the larger the elasticity of substitution between the two commodities, the smaller can sunk costs be, and the incumbent firm still maintain its monopoly position [Stiglitz (1988)].

\section{Does more potential competition make competition more effective?}

In the analysis so far, it makes little difference whether there is one or 
many potential competitors. There are some circumstances, however, where markets may be less competitive, the greater the number of potential competitors. The reason is simple: a firm's incentive to undertake the risk of entering a market, to take away some of the profits of the incumbent firm will be diminished if it believes that if it is initially successful in doing so, other firms will simply enter the market, to take its profits away.

But while potential competition may not provide an adequate discipline for the market, neither need the presence of several firms in the market. They may collude rather than compete. Until now, we have simply assumed that once entry occurs, Bertrand competition will break out. In fact, the principle of bygones-are-bygones applies to competitive strategies as well as to production decisions: once the entrant has entered, it may pay the incumbent firm to accommodate to that entry; in particular, the perfect equilibrium may entail collusion. This collusion may emerge even in finite period models. Consider, for instance, a three period model, in which if the firms do not cooperate, Bertrand competition breaks out. Accordingly, profits are zero. A firm that exits recovers an amount $\hat{F}>0$. There will exist mixed strategies, in which each firm leaves with a given probability; the expected value of profits for these strategies is $\hat{F}$. But joint profits are clearly higher if one firm leaves, and the other firm makes monopoly profits. There exists a perfect equilibrium in which one firm promises to exit, provided in the preceding period(s), the other firm cooperates in charging the monopoly price and dividing the market in an appropriate way [Stiglitz (1988)].

This example as well as several of the others presented depends on exit and entry (sunk) costs. ${ }^{6}$ These are endogenous, chosen by the firms as part of their strategies, taking into account the consequences.

\section{Technical change and sunk costs}

Our interest in a careful examination of sunk costs was motivated by the understanding which these models might provide on the role of potential and actual competition on $R \& D$, to which we now turn.

Early analytic results of Arrow (1962) had suggested that in the presence of product competition, there would be too little expenditure on $R \& D$, because if prices fell, the firm would not appropriate the consumer surplus; and if prices did not fall, the social gain would be less (again by the magnitude of the consumer surplus) than it would have been under a first best allocation. But R\&D under monopoly was even less, because the monopolists' output was smaller, and hence his gain from a marginal reduction in the cost of production was smaller. Arrow seemed to be directly challenging the Schumpeterian wisdom that monopoly was necessary for R\&D to occur.

${ }^{6}$ That part of entry costs which are not recovered upon exit can be thought of as sunk costs. 
The disparity in views was, however, more apparent than real. Arrow assumed a fully working patent system, which gave inventors a monopoly right over the invention; thus Arrow was completely unconcerned with the difficulties which arise in appropriating returns in competitive markets.

Moreover, Arrow's analysis was partial equilibrium. In a general equilibrium model, in which all industries are characterized by some degree of monopoly, some industries may have a higher output than under competition, some lower; there is no general presumption that $R \& D$ will be lower [Stiglitz (1985)]. Moreover, in his first best welfare comparisons, Arrow ignored the distortions associated with raising the revenues required to finance R\&D; the difference between market allocations (whether monopolistic or competitive) and the relevant second best welfare optimum may be much smaller than Arrow's earlier analysis had suggested.

Arrow had focused on the time-honoured polar models - monopoly and competition but most industrial sectors are oligopolistic, in which strategic competition - plays a central role; many of the insights gleaned from these polar cases do not carry over to this other arena, in which technological competition is often far more important than price competition. The relationship between R\&D and market structure is complex. If, for instance, ex post competition in the product market is Bertrand, market structure makes little difference [Sah and Stiglitz (1987)]; in other cases, an increase in competition lowers the pace of R\&D [Gilbert and Stiglitz (1979)]. ${ }^{7}$ In still other models, strategic considerations lead firms to accelerate their R\&D, but then postpone the introduction of the innovation (holding what are known as sleeping patents) [Dasgupta, Gilbert and Stiglitz (1978)].

But the most serious objection to this whole approach is that market structure was taken to be exogenous: the non-convexities which are at the heart of technical change are essentially incompatible with the persistence of perfectly competitive market structures. Market structure needs to be treated as an endogenous variable; and the nature of competition is critically affected by the characteristics of technological change. It was this concern which motivated the research programme that we began together in the mid-70's.

Several results emerged from our early investigations of the relationship between potential competition and welfare [Dasgupta and Stiglitz (1980a, 1980b)]. First, potential competition affected the behavior of incumbent firms. They were induced to engage in faster research, to pre-empt the entry of rivals. Secondly, the Schumpeterian picture of one firm being succeeded by another firm might not be accurate, as the incumbent firm seemed to have a decided advantage over potential entrants; we established the possibility of

\footnotetext{
'The intuition behind their result is simple. In their model, firms committed themselves to a level of research before they knew the research undertaken by others; equilibrium was characterized by a mixed strategy. The more firms in the market, the more duplication of research, and the slower the research programme had to be in order for the firms to break even.
} 
the persistence of monopoly [see also Salop (1979)]. ${ }^{8}$ Thirdly, potential competition neither drove profits to zero, nor, in general, ensured the attainment of (constrained) welfare optima.

But even before we published our earlier results, we became concerned that our analysis had over-stated the potential role for potential competition. ${ }^{9}$ Potential competition may be relatively ineffective in the presence of even small sunk costs. Expenditures on $R \& D$, and the process of improvement in production capabilities through learning by doing, fundamentally entail sunk costs. A firm that invested a small amount of sunk costs into a research programme could announce that it would meet any competition, winning the patent race. Not only could it make such an announcement, but the announcement would be credible. Entry would be deterred, and the incumbent would be able to carry on its research program essentially as if it were a monopolist. It can be shown that this strategy, which we referred to in our 1980(b) paper as $\varepsilon$-pre-emption, is a perfect equilibrium.

Similarly, when technical change is a result of production (learning by doing), if one firm has an $\varepsilon$ head start on others, the unique perfect equilibrium has it maintaining and extending that advantage, becoming the dominant firm. ${ }^{10}$

\section{Concluding remarks}

It would have been convenient if the scope of the Fundamental Theorem of Welfare Economics could have been expanded to cover modern industrial economies, to include natural monopolies and industries with technological change. Anti-trust could then focus its attention on government granted monopolies, and those maintained by other than economic forces (e.g., the Mafia). Our analysis suggests that the applicability of the presumption that market economics are efficient, that potential competition will serve to ensurc that profits are driven to zero and that efficiency is maintained, is much more circumscribed than had previously been thought; and that indeed, there may even be a trade-off between the discipline that potential competition can provide and the degree of ex post actual competition. Our analysis, suggests

\footnotetext{
${ }^{8}$ Gilbert and Newbery showed that even if the outcomes of R\&D were stochastic, the incumbent would pre-empt entrants. Of course, if the incumbent does not know the research programmes undertaken by potential rivals, it may or may not pay for him to anticipate all of them. If he does not, then there may be a succession of monopolists, as Schumpeter had envisaged. See Fudenberg, Gilbert, Stiglitz and Tirole.

${ }^{9}$ Reflected in a brief comment on p. 287 of Dasgupta and Stiglitz (1980b).

${ }^{10}$ When no firm has any advantage, in addition to the asymmetric equilibrium, in which one firm is a monopolist, there are (what may be mixed strategy) symmetric equilibrium; but these are clearly not robust to slight changes in the parameters of the problem. Thus we would contend that those models which have focused on the symmetric equilibrium have focused on the 'wrong' equilibrium. For a fuller discussion, see Dasgupta and Stiglitz (1988).
} 
that even small barriers to entry can give rise to large degrees of monopoly power, and that natural monopolies and oligopolies, arising from the large sunk costs and non-convexities associated with learning by doing and R\&D, are pervasive in modern industrial economies. But while Schumpeter may have been correct that some degree of competition is necessary for technological progress, there is no assurance that the level of monopoly which emerges in the market will be that which is most conducive to progress, let alone to the appropriate division of the gains from technological progress between consumers and producers.

\section{References}

Arrow, K.J., 1962, Economic welfare and the allocation of resources for invention, in: R. Nelson, ed., The rate and direction of inventive activity: Economic and social factors ((NBER) Princeton University Press).

Atkinson, A. and J.E. Stiglitz, 1976, The design of tax structure: Direct versus indirect taxation, Journal of Public Economics 6, 55-75.

Bain, J.S., 1956, Barriers to new competition (Harvard University Press, Cambridge, MA).

Baumol, WJ., 1982, Contestable markets: An uprising in the theory of industrial structure, American Economic Review 72, 1-15.

Baumol, W.J., E.E. Bailey and R.D. Willig, 1977, Weak invisible hand theorems and the sustainability of prices in a multiproduct monopoly, American Economic Review 67, 350365.

Baumol, W.J. and R.D. Willig, 1981, Fixed costs, sunk costs, entry barriers and sustainability of monopoly, Quarterly Journal of Economics, $405-432$.

Baumol, WJ., J.C. Panzar and R.D. Willig, 1982, Contestable markets and the theory of industry structure (Harcourt Brace Jovanovich, New York).

Bernheim, D., 1984, Strategic deterrence of sequential entry into an industry, The Rand Journal of Economics 15, no. 1 (Spring), 1984, 1-11.

Dasgupta, P. and J.E. Stiglitz, 1980a, Uncertainty, industrial structure, and the speed of R\&D, Bell Joumal of Economics (Spring) 11, 1-28.

Dasgupta, P. and J.E. Stiglitz 1980b, Market structure and the state of innovative activity, Economic Journal 90, 266-293.

Dasgupta, P. and J.E. Stiglitz, 1988, Learning-by-doing, market structure and industrial and trade policies, Oxford Economic Papers.

Dasgupta, P., R. Gilbert and J.E. Stiglitz, 1982, Invention and innovation under alternative market structures: The case of natural resources, Review of Economic Studies, XLIX, 1982, $568-582$.

Demsetz, H., 1968, Why regulate utilities? Journal of Law and Economics 11, 55-66.

Dixit, A.K., 1979, A model of duopoly suggesting a theory of entry barriers, Bell Journal of Economics 10, 20-32.

Dixit, A.K., 1980, The role of investment in entry deterrence, Economic Journal 90, 95-106.

Dixit, A.K. and J.E. Stiglitz, 1977. Monopolistic competition and optimal product diversity, American Economic Review 67, June, 297-308.

Eaton, B.C. and R.G. Lipsey, 1980, Exit barriers are entry barriers: The durability of capital as a barrier to entry, Bell Journal of Economics 10, 721-729.

Farrell, J., 1986, How effective is potential competition? Economic Letters 20, 67-70.

Fudenberg, D., R. Gilbert J. Tirole and J.E. Stiglitz, 1983, Preemption, leapfrogging, and competition in patent races, European Economic Review (June) 22, 3-32.

Gilbert, R.J., 1986, Pre-emptive competition, in: J. Stiglitz and F. Matthewson, ed., New Developments in Market Structure (MIT Press and MacMillan). 
Gilbert, R.J. and D.M.G. Newbery, 1982, Preemptive patenting and the persistence of monopoly, American Economic Review 782, no. 2.

Gilbert,R. and J.E. Stiglitz, 1979, Entry, equilibrium and welfare, Paper presented to a NBER conference, Toronto.

Grossman, S.J., 1981, Nash equilibrium and the industrial organization of markets with large fixed costs, Econometrica 49, 1149-1172.

Harris, C. and J. Vickers, 1985, Perfect equilibrium in a model of a race, Review of Economic Studies 52, 193-210.

Radner, R. and J.E. Stiglitz, 1979, A nonconcavity in the value of information, in: Marcel Boyer and Richard Khilstrom, eds., Bayesian models in economic theory (Elsevier Science Publications) 1984, 33-52.

Sah, R. and J.E. Stiglitz 1987, The invariance of R\&D to the number of firms in the industry: Equilibrium and efficiency under Bertrand competition, Rand Journal of Economics 18, 98-108

Salop, S.C., 1979, Strategic entry deterrence. American Economic Review 69. May. 335-338.

Sappington, D. and J.E. Stiglitz, 1987, Information and regulation, in: E. Bailey, ed., Public Regulation (MIT Press, London) 3-43.

Stiglitz, J.E., 1981, Potential competition may reduce welfare, American Economic Review 71, $184-189$.

Stiglitz, J.E., 1987, On the microeconomics of technical progress, in: Jorge M. Katz, ed., Technology generation in Latin American manufacturing industries (Macmillan. Hampshire).

Stiglitz, J.E., 1988, Sunk costs competition, and technical progress, Brookings Papers on Economic Activity.

Stiglitz J.E., 1985, Theory of competition, incentives and risk, in: J.E. Stiglitz and F. Mathewson, eds., Developments in the theory of market structure (MacMillan/MIT Press). 